Georgetown University Institutional Repository http://www.library.georgetown.edu/digitalgeorgetown

The author made this article openly available online. Please tell us how this access affects you. Your story matters.

\title{
Strategies of the Unemployed in South Africa: Does Moving Allow the Unemployed to Get Ahead?
}

Ebrahim, Leibbrandt, and Woolard. "Strategies of the Unemployed in South Africa: Does Moving Allow the Unemployed to Get Ahead?" Africanus: Journal of Development Studies, 46(1) 2016, pp. 52-75.

Collection Permanent Link: hdl.handle.net/10822/1042999

(C) Unisa Press

This material is made available online with the permission of the author, and in accordance with publisher policies. No further reproduction or distribution of this copy is permitted by electronic transmission or any other means. 


\section{STRATEGIES OF THE UNEMPLOYED IN SOUTH AFRICA: DOES MOVING ALLOW THE UNEMPLOYED TO GET AHEAD?}

\section{Amina Ebrahim}

University of Cape Town

amina.ebrahim@uct.ac.za

\section{Murray Leibbrandt}

University of Cape Town

murray.leibbrandt@uct.ac.za

\section{Ingrid Woolard}

University of Cape Town

ingrid.woolard@uct.ac.za

\section{ABSTRACT}

This paper examines the survival strategies of the unemployed by using the data from the 2008, 2010-2011 and 2012 National Income Dynamics Study. We find that in response to unemployment and almost no unemployment insurance, unemployed individuals look to parents, relatives and friends for economic support. They are more likely to attach themselves to households that have some income through an employed member or receipt of state support. In many cases, the unemployed delay setting up their own households while others move back into family households when faced with persistent unemployment. We use a probit model to show that the unemployed who move are more likely to be employed when interviewed the second or third time. The effects of moving on employment status are significant and positive when we take into account household and individual characteristics. Moving allows the unemployed to get ahead.

Keywords: Unemployment, Moving, Household composition

\section{UNISA}




\section{INTRODUCTION}

It is easy to understand why unemployment has been of particular interest in South Africa as the country has one of the highest unemployment rates in the world. Statistics South Africa reports an unemployment rate of $24.9 \%$ in 2012 with minor increases in 2013 and 2014 (Stats SA 2014). This figure is higher than that of some of South Africa's neighbouring countries and one of the highest in sub-Saharan Africa. For example, the unemployment rate was $18.2 \%$ in Botswana and $18.6 \%$ in Namibia in 2014 (World Bank 2014). South Africa's unemployment rate remains dismal when compared to other upper middle income countries such as Brazil (6.8\%) and Malaysia (2\%) (World Bank 2014).

In 2012, unemployment rates were $25 \%$ and $38 \%$, in urban and rural areas respectively, as reported in Table 1 below. We also note that unemployment rates continue to differ considerably according to race some 20 years after Apartheid ended in South Africa. Africans have the highest unemployment rate across the panel (32\% in 2012), followed by Coloureds (26\% in 2012), Indians (15\% in 2012) and lastly Whites (9\% in 2012).

Table 1: Unemployment rates by location and race

\begin{tabular}{|l|l|l|l|}
\hline Unemployment rate (\%) & $\mathbf{2 0 0 8}$ & $\mathbf{2 0 1 0}$ & $\mathbf{2 0 1 2}$ \\
\hline Rural & 36 & 39 & 38 \\
\hline Urban & 28 & 22 & 25 \\
\hline & & & \\
\hline African & 34 & 31 & 32 \\
\hline Coloured & 26 & 23 & 26 \\
\hline Indian & 15 & 15 & 15 \\
\hline White & 15 & 5 & 9 \\
\hline & & & \\
\hline All & 30 & 27 & 29 \\
\hline
\end{tabular}

Note: Own estimates using full samples of NIDS (SALDRU, 2013a; 2013b; 2013c). Observations weighted using post-stratification weights.

Little to no direct support for the unemployed exists in the form of unemployment insurance (Leibbrandt, Woolard and Arden 2010). Only 0.1\% of the sampled unemployed in 2012 NIDS data reported receiving payments from the Unemployment Insurance Fund (UIF) in the preceding month (Southern Africa Labour and Development Research Unit [SALDRU] 2013c). The fund provides insurance only to those who previously contributed to it while working. Unemployed youth are unlikely to be able to make use of this fund as they would not have had a chance to contribute to it. The high unemployment rates in rural and urban areas, coupled with 
little insurance, beg the question about the coping strategies the unemployed seek in order to survive.

Alongside this, little scholarly attention has been paid to household composition and moving in Africa. However, increasingly, more work is surfacing around the topic in South Africa with attention being paid to the effect of the social security system and labour migration on household composition (Budlender and Lund 2011; Posel, Fairburn and Lund 2006) and, to a lesser extent, to the effect of employment on household formation (Keller 2004).

Household composition is endogenous to a variety of welfare issues, and little is understood about the determinants of this composition. During apartheid the movement of Africans, Coloured and Indians was restricted through an elaborate system of pass laws enacted by the Group Areas Act (Act No. 41. of 1950). The government allowed African individuals to migrate to urban areas to work, but they were not allowed to have their families move with them (Thompson 1990).

Movement within and out of South Africa continues post-apartheid and may be temporary, when the migrant leaves behind a family and returns to their household from time to time, or permanent, from one district to another. Moving is often associated with finding employment (Pekkala and Tervo 2002). Understanding migration within South Africa and the household formation decision may improve our understanding of how the unemployed gain access to resources in order to survive.

Previous studies point out that the unemployed attach themselves to households where some economic support exists (Klasen and Woolard 2009; Keller 2004). In many cases the unemployed have to move to rural areas, where they have family and communities to support them. However, doing this takes them away from job opportunities that may arise in urban areas. Furthermore, supporting the unemployed becomes a burden for resource-constrained rural households and may drag them deeper into poverty.

By investigating the movement of the unemployed, we will bring to light some of the most important choices made by the unemployed in order to access resources and survive. This paper will investigate two main strategies of the unemployed: to stay in households that provide them with support, and to move to other households in search of employment or support. In section 2, we present relevant local and international literature on unemployment, household formation and moving to inform our model at the end of the section. In section 3, we discuss the data and its suitability for this analysis. In section 4 , we estimate the effect of moving on the unemployed, and finally, in section 5, we make concluding remarks.

In order to survive with no insurance and low employment prospects, the unemployed look to immediate and extended family for support. It seems that those who are able to access resources do move and we show that they benefit from such a move. Those that cannot access such resources, remain where they are as it is the best that they can do given their constraints. 


\section{LITERATURE AND ECONOMIC MODEL}

We examine the existing international and South African literature on the location decision of the unemployed. Using the previous literature to guide us, we develop an informed research approach to understand this issue in South Africa.

\section{International Literature}

The international literature on the survival of the unemployed is concentrated in developed countries. It focusses predominantly on the determinants of household formation for young people entering the labour market (Card and Lemieux 1997; Ermisch and Di Salvo 1997).

McElroy (1985) examines a model of household membership, employment and consumption. She proposes a Nash bargaining model for family behaviour that suggests that the decision whether to live with parents or to move out is decided jointly with the employment decision. For example, a youth will choose his/ her consumption and leisure bundle and the associated household membership to maximise his utility (McElroy 1985). She finds that families in the United Kingdom are likely to provide their young adult sons with informal 'unemployment insurance' when they are faced with poor labour market opportunities.

Rosenzweig and Wolpin (1994) examine the effect of support of young adults through transfers or co-residence in the USA. They suggest that young adults may choose to delay moving out of their family home in response to unemployment. This choice of co-residency can be viewed as an intergenerational transfer from parents to their children. The authors consider co-residency to be a less expensive way for families to support their unemployed children. In comparison to providing them with transfers, co-residency comes at a cost to one's privacy (Rosenzweig and Wolpin 1994).

Card and Lemieux (1997) find that, in the Canadian context, poor labour market conditions are a cause of higher percentages of youth remaining with their families in comparison to the USA. They make use of panel data over a 25-year period and examine the effect of labour market forces on household composition, school attendance and workforce participation.

Pekkala and Tervo (2002) use data from the Finnish longitudinal population census to investigate whether moving helps the unemployed. The authors argue that those with more favourable employment prospects are more likely to migrate, which would cause a selection bias. To deal with this issue, the authors use housing prices and household ownership as the instruments for measuring migration. They show that the instruments are uncorrelated with employability and use the instrumental variable approach to deal with the problem of selection bias. They find that moving did not have a significant effect on employment status for a sample of working-age Finnish in 1996. 
Ermisch and Di Salvo (1997) suggest that in response to unemployment, youth in the UK will delay leaving their family homes and may even return. They examine the effect of the price of housing, parental income, potential future income and individual characteristics on the household formation decision of a cohort of British youth. The authors use a dynamic two-stage model. In the first stage, they model the utility of parents providing transfers to their children, among other variables, conditional on their budget constraints. In the second stage, the authors model the choice of the youth to remain with their parents. The higher the exogenous housing price, the less likely it becomes that the child leaves the parental home. The authors predict that a higher income increases the probability of the child leaving home while a higher parental income reduces it. This implies that they are more likely to follow the strategy with the best economic support.

Wiemers (2014) suggests that one way in which individuals and families can cope with job loss is by 'doubling up' (sharing living arrangements) with family and friends. She uses panel data from the USA and finds that individuals who become unemployed are three times more likely to move in with other people. She also finds that doubling up is most common among those with less than a high school diploma and those with at least some college using a linear probability model.

Keller (2004) finds a similar result in the South African context: higher parental income reduces the likelihood of moving out.

\section{South African Literature}

There are dangers in mechanically applying the international literature to the South African context. Unemployment in South Africa is concentrated amongst the youth and in rural areas with limited labour market opportunities and access to information. We also note that household formation decisions are likely to be influenced by cultural and ethnic norms of South Africa (Neves and Du Toit 2008).

The South African literature on the unemployed, household composition and moving has been dominated by discussions on the South African non-contributory old-age pension and its effect on labour supply (Ardington, Case and Hosegood 2009; Edmonds, Mammen and Miller, 2005; Madhavan, Schatz and Clarke 2012; Posel, Fairburn and Lund 2006).

Edmonds, Mammen and Miller (2005) use a regression discontinuity design to measure the household response, including the unemployed, when a member becomes eligible for an old-age pension at the age of 60 . The authors use census data and find that the presence of a pensioner has an effect on household composition. In response to a woman receiving a pension income, the household will include fewer prime-aged women, who migrate in search of work. In response to a man receiving the pension, the household will lose its prime-aged men to labour migration. This implies that an increase in household income provides the opportunity for the working-age members who wish to seek employment to leave the home. 
Pensioners living in multigenerational households share their pension income with their families (Møller and Sotshongaye 1996; Sagner and Mtati 1999). This sharing of income increases the resources available to support the unemployed.

Ardington, Case and Hosegood (2009) examine the effect of the presence of a pensioner in the household on employment and moving by using panel data from a poor rural district in KwaZulu-Natal. They find that a household that receives an old-age pension has higher employment rates for prime-aged household members, as well as increased labour migration among the prime-aged members. This evidence suggests that an exogenous increase in household income from the old-age pension provides much needed support to the unemployed and even allows them to migrate in search of employment.

Using a combination of panel and cross-sectional data, Klasen and Woolard (2009) study the household formation choices of the unemployed with the use of a multinomial logit model. The authors look at the effect of unemployment on the unemployed person's relationship to the household head. Under the hypothesis that the unemployed are likely to attach themselves to a household for economic support, the authors suggest that the unemployed are less likely to be the head of a household. They find that the unemployed are more likely to live with their parents, family or non-family to seek support relative to being the household head or spouse of the household head. The authors examine panel data to show that those who remained unemployed or became unemployed between 1993 and 1998 remained in their parental home and delayed setting up their own households. This is similar to findings in the international literature.

Keller (2004) models the effect of employment status on household-head status using a cross section of male Africans in rural South Africa. She uses a probit model with selection to capture the simultaneous determination of employment and household head status. The results from the model are similar to those of Klasen and Woolard (2009); that is, the unemployed are less likely to move out and set up households while the employed are more likely to be household heads.

The South African literature has thus far used national cross-sectional data (Keller 2004) or region-specific panel data (Klasen and Woolard 2009), which points to the need for national panel data to examine the strategies of the unemployed. Panel data is often preferred, as it allows one to overcome the problem of potential unobserved heterogeneity. In the context of employment, personal characteristics such as innate ability do not change over time. There is value to be gained from following people as they move and respond to changes in employment status.

\section{Economic Model - The Location Decision of the Unemployed}

The international literature models the choice of the unemployed between moving and staying with parents. In the South African context, this idea has been extended 
to include other options such as staying with extended family, or non-family, taking into account the cultural norms (Neves and Du Toit 2008). The findings from the South African literature endorse this approach (Keller 2004; Klasen and Woolard 2009).

This extension also affects the kind of income variable used in our model. In the international literature, parental income is often used as a factor to determine the location decision of the youth. In South Africa, in the context of extended families, the income of other household members is shared with everyone in the household (Møller and Sotshongaye 1996; Sagner and Mtati 1999). Furthermore, the South African literature tells us that many parents may have temporarily migrated for work. We thus use household income instead of parental income in our model.

We consider a similar framework to that of Klasen and Woolard (2009). We treat employment as exogenous, while acknowledging that in the medium to long term the labour market and location decision may be a joint one. We assume the individual maximises his or her utility according to the budget constraint determined by the different household arrangements and their locations. Variables in the utility function of moving out include the individual's wage income, non-wage income and the prices of consumption goods.

When attaching to a household, the unemployed benefit from a share of the income of the other household members. We account for this by including per capita household income; however, it may be endogenous, so we consider the model with and without this variable (Klasen and Woolard 2009).

The cost of attaching to a household includes the cost to one's privacy and the discounted future value of wages constrained by the location of the household. That is, if the household is in a rural area, the unemployed are removed from possible employment opportunities (Klasen and Woolard 2009, 9).

$$
v(\text { moving unattached })=f(w, I, p, G)
$$

\section{Equation 1}

$$
v(\text { staying attached })=\left(w, I, p, c_{p}, \delta \operatorname{Pr}(w), \frac{Y_{h}}{n_{h}}\right)
$$

\section{Equation 2}

Equation 1 represents the indirect utility of living alone; $w$ represents the wage rate, $I$ is the non-wage income and $p$ refers to price. Equation 2 describes the indirect utility of sharing a household with others; $c_{p}$ refers to the privacy cost, $\delta \operatorname{Pr}(w)$ is the lost wages or discounted future value of wage from being attached to a household with 
limited employment prospects and finally, $\frac{Y_{h}}{n_{h}}$ represents the income per capita in the household calculated as the household income divided by the household size.

Within this framework, it is the employed who earn a wage enabling them to move out and live alone. Living with others becomes less likely as the benefit of the shared income becomes lower, and the cost of privacy increases with age. Older, married and employed individuals will place greater value on privacy and reduce the likelihood of living with parents or others. A further cost of being attached to another household is the location of that household. If the choice of where to live brings the unemployed closer to improved labour market conditions, this situation makes the unemployed individual who moves more likely to be employed.

In this framework, it is more appealing for someone with no wages to attach themselves to a household in order to share in the income of other members. The higher the household's per capita income, the more attractive it will be for an unemployed person but the discounted future earnings may be low, depending on the location of the household and the surrounding labour market conditions.

With the use of this framework, we examine the strategy of the unemployed to remain in income bearing households or to move in search of support. We then show that moving is beneficial for the unemployed.

\section{DATAAND DESCRIPTIVE SITUATION}

\section{Data and Sample characteristics}

The National Income Dynamics Study (NIDS) (Southern Africa Labour and Development Research Unit [SALDRU] 2013c) tracks a nationally representative sample of South Africans over time. It is the change in location that is unique to NIDS and particularly important for this study. Each wave of the fieldwork tracks those who move around South Africa and interviews them at their current residence. The dataset contains variables related to whether individuals moved or stayed within the same location as well as the distance they moved (De Villiers et al. 2013).

The NIDS panel currently consists of three waves of survey data collected in 2008, 2010 and 2012. A total of 28,247 individuals were interviewed in the first wave, 28,641 individuals in the subsequent wave; and 32,633 individuals in the third wave in 2012.

Our central interest lies in changes over time in location of the wave 1 unemployed individuals. For this reason, we exclude the wave 1 non-resident household members who do not continue as members of the sample. We further exclude individuals who left the sample in waves 2 and 3. Taking into account these exclusions, there are 18,818 individuals who are continuing sample members making up the balanced panel. 
Table 2: Characteristics of sample members

\begin{tabular}{|c|c|c|}
\hline \multicolumn{3}{|l|}{ Wave 1-unemployed } \\
\hline & Full sample (\%) & Balanced panel (\%) \\
\hline \multicolumn{3}{|l|}{ Race } \\
\hline African & 84.9 & 88.3 \\
\hline Coloured & 8.1 & 7.0 \\
\hline Indian & 1.4 & 1.6 \\
\hline White & 5.6 & 3.1 \\
\hline \multicolumn{3}{|l|}{ Gender } \\
\hline Men & 37.1 & 34.5 \\
\hline Women & 62.9 & 65.5 \\
\hline \multicolumn{3}{|l|}{ Location } \\
\hline Urban & 36.1 & 38.6 \\
\hline Rural & 63.9 & 61.4 \\
\hline \multicolumn{3}{|l|}{ Age categories } \\
\hline $15-18$ & 5.2 & 4.7 \\
\hline $19-23$ & 23.3 & 22.0 \\
\hline $24-28$ & 21.1 & 20.8 \\
\hline $29-34$ & 19.0 & 19.1 \\
\hline $35-44$ & 19.5 & 20.2 \\
\hline $45-59$ & 11.9 & 13.2 \\
\hline \multicolumn{3}{|l|}{ Education } \\
\hline No schooling & 5.6 & 5.8 \\
\hline Primary school & 17.7 & 16.9 \\
\hline Some secondary & 47.8 & 48.3 \\
\hline Secondary school & 28.2 & 28.6 \\
\hline Post-secondary & 0.7 & 0.5 \\
\hline Number of observations & 3252 & 2,196 \\
\hline Weighted observations & $6,002,427$ & $4,884,978$ \\
\hline
\end{tabular}

Note: Own estimates using full samples of NIDS (SALDRU, 2013a; 2013b; 2013c). Observations in the full sample weighted using post-stratification weights and observation in the balanced panel sample weighted with calibrated panel weights.

We examine and compare the unemployed from all those sampled in wave 1 and the unemployed from the balanced panel in Table 2 above. 
According to Table 2, the balanced panel is broadly similar with some small differences when compared to the full sample in the characteristics shown. We wish to track the movement of those in the sample; thus, the panel sample of unemployed is better suited as our analytical sample. This will allow us to track an individual's response to changes in employment status in successive waves.

Table 2 above makes use of the panel weights in the balanced panel and all subsequent analysis will do the same. The panel weights are based on the calibrated weights of the sampled individuals and account for attrition bias in basic demographic variables. As can be seen from the table, when using the panel weight, our balanced panel seems to retain reasonable respresentativity.

\section{Employment Status}

Cichello, Leibbrandt and Woolard (2012) note that the unemployment rates in wave 2 of the data are lower than expected, perhaps due to some of the unemployed being categorised as not economically active, when in fact they were unemployed. To address this issue, we look at the wave 1-unemployed and their decisions to stay or move in waves 2 and 3. In our empirical work, we rely on the broad definition of the unemployed; those who report being unemployed and searching for employment as well as those desiring to work but not looking for a job.

When examining a change in employment status, we include adults of a working age. We choose a lower age limit of 15, as some teenagers are not in school but are working to support their families, and an upper age limit of 59 as those older than this age are eligible for the state old-age pension.

\section{Remittances, Pensions and Grants}

We begin our examination of the unemployed by looking at the households in which they live in each of the three years of the NIDS panel. Below we show that the economic support available to the unemployed goes beyond income from an employed household member. Some households derive their income from remittances or the social assistance system. Earlier, we describe these as private and public safety nets respectively. Households with an income are attractive to the unemployed as they can provide economic support. However, many of these households are located in rural areas, away from labour market opportunities, making it harder to find employment.

Using the balanced panel, Table 3 reports the type of households with economic support and the households which the unemployed seek support from. The top half of the table reports the share of households containing various combinations of employed and incoming-receiving individuals. The bottom half of the table describes the types of households in which unemployed respondents live. 
Table 3: Household support and the unemployed

\begin{tabular}{|c|c|c|c|c|c|c|}
\hline \multicolumn{7}{|l|}{ Household-level analysis } \\
\hline & \multicolumn{3}{|c|}{ All (\%) } & \multicolumn{3}{|c|}{ African (\%) } \\
\hline & 2008 & 2010 & 2012 & 2008 & 2010 & 2012 \\
\hline $1+$ employed & 60.2 & 58.5 & 59.5 & 58.2 & 56.2 & 58.7 \\
\hline No employed, remittances & 7.8 & 4.5 & 6.8 & 8.6 & 5.2 & 7.6 \\
\hline $\begin{array}{l}\text { No employed, no remittances, } \\
\text { grants }\end{array}$ & 19.3 & 21.6 & 20.0 & 20.9 & 24.0 & 21.4 \\
\hline $\begin{array}{l}\text { No employed, no remittances, no } \\
\text { grants }\end{array}$ & 12.8 & 15.4 & 13.7 & 12.4 & 14.6 & 12.3 \\
\hline \multicolumn{7}{|l|}{ Individual-level analysis } \\
\hline & \multicolumn{3}{|c|}{$\begin{array}{l}\text { All unemployed } \\
(\%)\end{array}$} & \multicolumn{3}{|c|}{$\begin{array}{l}\text { African unemployed } \\
(\%)\end{array}$} \\
\hline & 2008 & 2010 & 2012 & 2008 & 2010 & 2012 \\
\hline 1+ employed & 45.8 & 38.5 & 41.2 & 42.8 & 36.3 & 38.8 \\
\hline No employed, remittances & 7.9 & 6.6 & 7.8 & 8.2 & 7.1 & 8.4 \\
\hline $\begin{array}{l}\text { No employed, no remittances, } \\
\text { grants }\end{array}$ & 33.8 & 31.9 & 33.9 & 35.8 & 32.7 & 34.8 \\
\hline $\begin{array}{l}\text { No employed, no remittances, no } \\
\text { grants }\end{array}$ & 12.5 & 23.0 & 17.0 & 13.3 & 23.9 & 18.1 \\
\hline
\end{tabular}

Note: Own estimates using working-age sample of NIDS (SALDRU, 2013a; 2013b; 2013c). Observations weighted using calibrated panel weights

We categorise all households into a set of discrete household types to depict a national breakdown of household types by income support. The top half of the table disregards where the unemployed reside. The categorisation shows the various household types from which the unemployed could seek support.

The first household type we examine is one where at least one or more persons in the household receive an income. This household type may include, but is not limited to, a pensioner receiving a pension income, an employed member working elsewhere and sending an income to the household or simply a household member who is employed.

The second category of household we examine is one where there are no employed members of the household but someone, not residing in the household, working elsewhere and remitting income to the household. Post-apartheid South Africa still has a large migrant labour system (Grieger, Williamson and Leibbrandt 2013) adding to the private safety net of an employed household member as we discuss above. 
The third category looks at a household with no employed individual and which is not in receipt of a wage income but derives the household income through state support, including through the old-age pension, the child support, the foster care, the disability and the care dependency grants.

The final and most vulnerable category of households is those with no employed members, which receive no remittance income and do not receive any state support.

The table reveals that almost a third of households are disconnected from the labour market with no employed household members, present or absent. More than 13\% of households in 2012 fall into the category of households that report having no income. These households may be less attractive to the unemployed as they are unable to provide economic support.

Many of the households that do receive remittances or social assistance that could provide some economic support to the unemployed are located in rural areas. While this type of household could provide economic support to the unemployed, the location of these households takes them away from the labour market opportunities they would otherwise be exposed to in urban areas.

The bottom half of Table 3 describes the location of the unemployed categorised under the same household types described above. In 2008, 45.8\% of the unemployed resided in households with at least one employed person. This figure decreased to $38.5 \% \%$ in 2010 and then increased to $41.2 \%$ in 2012. The figures for the Africanonly sample are slightly lower. As expected, residing in a household with at least one employed person is the most popular choice for an unemployed individual requiring economic support.

Almost $8 \%$ of the unemployed live in households with no employed member which received remittances in 2008, with figures dropping to $6.6 \%$ in 2010 and increasing again to $7.8 \%$ in 2012 .

However, the second largest proportion of the unemployed resides in households with no employed member and no remittance income but with at least one member receiving state support. In 2008, 33.8\% of the unemployed lived in a household where no other member was employed and no member in the household received a remittance, but someone in the household was in receipt of a grant income. In 2010, the proportion decreased to $31.9 \%$ and again increased to $33.9 \%$ in 2012 . This shows the reach of the social assistance system in South Africa, as Keller (2004) suggests, as well as the pressure on grant holders to share their income.

The remainder of the unemployed reside in households that do not receive state support and that have no connection to the labour market and no remittance income. This group makes up $12.5 \%$ of the sample in $2008,23 \%$ of the sample in 2010 and $17 \%$ of the sample in 2012 . These figures are comparable to those reported in Klasen and Woolard (2009) for 2004. It is of concern that so many unemployed are not protected through private or public safety nets. This group of unprotected unemployed has almost no access to resources in order to find employment or move. 
Since this is the least attractive household type for the unemployed, due to its lack of available economic support, we expected these numbers to be lower.

We have established that when the unemployed are attached to households, they are most often in a household that receives a grant or wage income. However, there are some unemployed who find themselves in households with no access to an income. Very few unemployed were found to be living alone.

\section{Do the Unemployed Move?}

Between wave 1 and 3, we observe that 2,097 individuals from the balanced panel had moved. Moving is defined as residing in a different building in a successive wave. Verified using (non-public access) GPS data, household members in the survey are classified as having moved if they changed residences between waves. In very few cases, all the members of the household move; most cases were individual moves which left other household members behind. Individuals may move within the same area but join a different household. Moves may take place between rural and urban areas, but also occur within rural and urban areas. Household members in the survey are coded as stayers if they have not changed residences between waves. We examine how this movement affects the unemployed.

Table 4: Wave 1-Unemployed movement in waves 2 and 3

\begin{tabular}{|l|l|l|}
\hline Wave 1-unemployed & Wave 2 (\%) & Wave 3 (\%) \\
\hline Migration in later waves & & \\
\hline Mover & 11.7 & 14.5 \\
\hline Stayer & 88.3 & 85.5 \\
\hline & & \\
\hline Employment status in later waves & & \\
\hline Not economically active & 39.6 & 27.3 \\
\hline Unemployed & 28.8 & 32.8 \\
\hline Employed & 31.6 & 40.0 \\
\hline
\end{tabular}

Note: Own estimates using working-age sample of NIDS (SALDRU, 2013a; 2013b; 2013c). Observations weighted using calibrated panel weights

A simple examination of the movement of the unemployed indicates that $11.7 \%$ had moved by wave 2 and $14.5 \%$ of the wave 1 -unemployed had moved by wave 3 .

At the same time, we see that some have gained employment in subsequent waves. We do not know the degree to which finding employment is driven by the move of the unemployed to survive or the support of living with parents or family. 
In trying to understand how moving affects employment status, we compare the household composition of movers and stayers of wave 1 (both the unemployed and all those in our wave 1 balanced panel sample) in Table 5 below. In the top part of the table, we see that, from our sample of unemployed working-age individuals, $14.3 \%$ had moved between waves 1 and 3. In the top right-hand corner of the table, we see that the unemployed have a slightly higher propensity to move in comparison to the rest of the balanced panel of which only $12.8 \%$ had moved.

Table 5: $\quad$ Movement between waves 1 and 3

\begin{tabular}{|l|l|l|l|l|l|}
\hline & \multicolumn{4}{|l|}{ Wave 1 } & \multicolumn{2}{l|}{ All (\%) } \\
\hline & & Unemployed (\%) & Mover & Stayer \\
\hline & Mover & Stayer & 12.8 & 87.2 \\
\hline Wave 3 - All & 14.3 & 85.7 & 12.8 & 60.5 \\
\hline HH head/spouse & 83.0 & 57.9 & 74.3 & 23.7 \\
\hline Living with parents & 8.4 & 23.5 & 10.0 & 15.7 \\
\hline Living with family & 8.0 & 18.5 & 15.5 & 0.1 \\
\hline Living with non-family & 0.6 & 0.1 & 0.2 & 100.0 \\
\hline Column total & 100.0 & 100.0 & 100.0 & \\
\hline \multicolumn{7}{|l}{} & & & 88.7 \\
\hline Wave 3 - Unemployed & 12.2 & 87.8 & 11.3 & 44.9 \\
\hline HH head/spouse & 87.2 & 51.6 & 74.4 & 35.3 \\
\hline Living with parents & 7.4 & 28.8 & 12.4 & 19.7 \\
\hline Living with family & 5.4 & 19.5 & 13.0 & 0.1 \\
\hline Living with non-family & 0.0 & 0.2 & 0.2 & 100.0 \\
\hline Column total & 100.0 & 100.0 & 100.0 & \\
\hline
\end{tabular}

Note: Own estimates using working-age sample of NIDS (SALDRU, 2013a; 2013b; 2013c). I Observations weighted using calibrated panel weights

More than $16 \%$ of the unemployed movers join the households of their parents $(8.4 \%)$ or family $(8 \%)$. A sizeable share of the unemployed stayers $(42.1 \%)$ remain living with parents, family and others. Both the unemployed stayers and movers presumably live with parents or family due to the comfort provided by the financial support of the household.

Those who are still unemployed in wave 3 have a higher propensity to stay with their support structures, as can be seen in the bottom section of Table 5. In comparison to the balanced panel, a smaller percentage of those who are still unemployed move.

The results from Tables 5 confirm that the unemployed will remain where they have the best access to economic resources. This means that in the face of low employment prospects and no unemployment insurance, the unemployed make use 
of private and public safety nets. The information about moving goes further and tells us that the main survival strategies for the unemployed are to remain in the household of their parents or family, and to a lesser degree, to move into a household with parents or family. We now explore whether the strategies of moving enable the unemployed to get ahead.

In Table 6, we describe the gains of moving and staying for the unemployed on their household real log per-capita income. The first row displays all the workingaged respondents in the balanced sample and the second row includes only the working-aged unemployed from the balanced panel. On the whole, movers gain more than stayers do in terms of the change in the real log per capita household income between waves 1 and 3. When isolating the unemployed, we see that the movers make greater gains than the stayers in terms of household per capita income between waves.

Table 6: Changes in real log per capita household income of the unemployed between waves

\begin{tabular}{|l|l|l|l|}
\hline \multicolumn{4}{|l|}{ Wave 1 - Wave 3 } \\
\hline Population & Movers & Stayers & Both \\
\hline All & 0.5641 & 0.1956 & 0.2433 \\
\hline & $(0.0659)$ & $(0.0226)$ & $(0.0234)$ \\
\hline Unemployed & 0.6321 & 0.3545 & 0.3948 \\
\hline & $(0.1260)$ & $(0.0413)$ & $(0.0446)$ \\
\hline
\end{tabular}

Note: Own estimates using working-age sample of NIDS (SALDRU, 2013a; 2013b; 2013c). Observations weighted using calibrated panel weights Standard errors reported in parentheses.

The evidence from Table 5 and 6 suggests that moving allows the unemployed to get ahead. However, employment could be dependent on many other variables. We will now take into account all the other factors we think may be affecting employment to see whether moving persists as a factor for getting ahead.

\section{FINDINGS}

\section{Moving as a Strategy to Escape Unemployment}

As discussed in section 2.3, we assume in our model that an individual maximises his or her utility such that his/her decisions are based on future costs and benefits. We are interested in whether employment in wave 3 was due to moving. Employment status is thus determined as: 


$$
E_{i}=\beta^{\prime} X_{i}+u_{i}
$$

\section{Equation 3}

In Equation 3, $X_{i}$ is the vector that contains moving status, individual and household demographics. We are interested in the coefficient of moving status, that is, the effect of moving on employment status.

In looking at the effect of moving on the sample of wave 1-unemployed, our expectation is that those who have more skills and education are likely to move in search of employment opportunities.

We consider a binary probit regression model predicting the possibility of employment associated with moving. We use the binary employment status variable in wave 3 as our dependent variable, where 1 reflects being employed and 0 reflects being unemployed or not economically active. Table 7 reports the marginal effects of the probit regression. The marginal effect provides an estimate of the change in the probability of gaining employment associated with moving between waves 1 and 3 . Controls include age, education levels, gender and location in the base year.

Columns 2 and 3 include controls for household income characteristics. Column 4 combines both individual and household income characteristics. Column 5 includes log per capita household income and, lastly, in column 6 we control for a move in wave 2 .

Table 7: Effect of moving on employment status for the wave 1-unemployed

\begin{tabular}{|l|l|l|l|l|l|l|}
\hline & $\begin{array}{l}\text { (1) } \\
\text { Moving } \\
\text { only }\end{array}$ & $\begin{array}{l}\text { (2) } \\
\text { Moving } \\
\text { with } \\
\text { household } \\
\text { grant } \\
\text { income } \\
\text { control }\end{array}$ & $\begin{array}{l}\text { (3) } \\
\text { Moving } \\
\text { with } \\
\text { household } \\
\text { income } \\
\text { controls }\end{array}$ & $\begin{array}{l}\text { (4) } \\
\text { Moving } \\
\text { with HH } \\
\text { income } \\
\text { and } \\
\text { individual } \\
\text { controls }\end{array}$ & $\begin{array}{l}\text { (5) } \\
\text { Moving } \\
\text { with Per } \\
\text { capita HH } \\
\text { income } \\
\text { and } \\
\text { individual } \\
\text { controls }\end{array}$ & $\begin{array}{l}\text { (6) } \\
\text { Moving } \\
\text { with a } \\
\text { control } \\
\text { for an } \\
\text { early } \\
\text { mover }\end{array}$ \\
\hline Mover & $0.147^{* * *}$ & $0.145^{* * *}$ & $0.145^{* * *}$ & $0.133^{* * *}$ & $0.136^{* * *}$ & $0.130^{* * *}$ \\
\hline & $(0.0398)$ & $(0.0393)$ & $(0.0394)$ & $(0.0382)$ & $(0.0382)$ & $(0.0391)$ \\
\hline Early mover & & & & & & 0.0770 \\
\hline & & & & & & $(0.0549)$ \\
\hline
\end{tabular}




\begin{tabular}{|c|c|c|c|c|c|c|}
\hline & $\begin{array}{l}\text { (1) } \\
\text { Moving } \\
\text { only }\end{array}$ & $\begin{array}{l}\text { (2) } \\
\text { Moving } \\
\text { with } \\
\text { household } \\
\text { grant } \\
\text { income } \\
\text { control }\end{array}$ & $\begin{array}{l}\text { (3) } \\
\text { Moving } \\
\text { with } \\
\text { household } \\
\text { income } \\
\text { controls }\end{array}$ & \begin{tabular}{|l|} 
(4) \\
Moving \\
with HH \\
income \\
and \\
individual \\
controls
\end{tabular} & $\begin{array}{l}(5) \\
\text { Moving } \\
\text { with Per } \\
\text { capita HH } \\
\text { income } \\
\text { and } \\
\text { individual } \\
\text { controls }\end{array}$ & $\begin{array}{l}(6) \\
\text { Moving } \\
\text { with a } \\
\text { control } \\
\text { for an } \\
\text { early } \\
\text { mover }\end{array}$ \\
\hline \multirow{2}{*}{$\begin{array}{l}\text { HH receives } \\
\text { grant income } \\
\text { in wave } 1 \\
(=1) \\
\text { ( })\end{array}$} & - & $-0.105^{* * *}$ & $-0.105^{* * *}$ & $-0.0790^{\star *}$ & - & - \\
\hline & & $(0.0364)$ & (0.0364) & $(0.0381)$ & & \\
\hline \multirow{2}{*}{$\begin{array}{l}\mathrm{HH} \text { receives } \\
\text { wage income } \\
\text { in wave } 1 \\
(=1) \\
\text { (=1) }\end{array}$} & - & - & 0.00183 & -0.00175 & - & - \\
\hline & & & $(0.0400)$ & $(0.0434)$ & & \\
\hline \multirow{2}{*}{$\begin{array}{l}\text { Log per } \\
\text { capita } \\
\text { household } \\
\text { income in } \\
\text { wave } 1\end{array}$} & & & & & -0.0184 & -0.0212 \\
\hline & & & & & $(0.0201)$ & $(0.0201)$ \\
\hline Female $(=1)$ & - & - & - & $-0.138^{* * *}$ & $-0.147^{\star * *}$ & $-0.150^{* * *}$ \\
\hline $\begin{array}{l}\text { Male } \\
\text { (omitted) }\end{array}$ & & & & $(0.0310)$ & $(0.0306)$ & $(0.0306)$ \\
\hline $\begin{array}{l}\text { Urban }(=1) \text { in } \\
\text { wave } 1\end{array}$ & - & - & - & $0.0695^{\star *}$ & $0.0907^{* * *}$ & $0.0866^{* * *}$ \\
\hline $\begin{array}{l}\text { Rural } \\
\text { (omitted) }\end{array}$ & & & & $(0.0315)$ & $(0.0327)$ & $(0.0326)$ \\
\hline \multicolumn{7}{|l|}{$\begin{array}{l}\text { Education: } \\
\text { No schooling } \\
\text { (Omitted) in } \\
\text { wave 1 }\end{array}$} \\
\hline \multirow[t]{2}{*}{$\begin{array}{l}\text { Primary } \\
\text { school }\end{array}$} & - & - & - & $-0.144^{* *}$ & $-0.132^{\star *}$ & $-0.135^{\star *}$ \\
\hline & & & & $(0.0618)$ & $(0.0626)$ & $(0.0629)$ \\
\hline $\begin{array}{l}\text { Some } \\
\text { secondary } \\
\text { school }\end{array}$ & - & - & - & $-0.107^{*}$ & -0.0893 & -0.0927 \\
\hline
\end{tabular}




\begin{tabular}{|c|c|c|c|c|c|c|}
\hline & $\begin{array}{l}\text { (1) } \\
\text { Moving } \\
\text { only }\end{array}$ & $\begin{array}{l}\text { (2) } \\
\text { Moving } \\
\text { with } \\
\text { household } \\
\text { grant } \\
\text { income } \\
\text { control }\end{array}$ & $\begin{array}{l}\text { (3) } \\
\text { Moving } \\
\text { with } \\
\text { household } \\
\text { income } \\
\text { controls }\end{array}$ & $\begin{array}{l}(4) \\
\text { Moving } \\
\text { with HH } \\
\text { income } \\
\text { and } \\
\text { individual } \\
\text { controls }\end{array}$ & $\begin{array}{l}(5) \\
\text { Moving } \\
\text { with Per } \\
\text { capita HH } \\
\text { income } \\
\text { and } \\
\text { individual } \\
\text { controls } \\
\end{array}$ & $\begin{array}{l}\text { (6) } \\
\text { Moving } \\
\text { with a } \\
\text { control } \\
\text { for an } \\
\text { early } \\
\text { mover }\end{array}$ \\
\hline & & & & $(0.0606)$ & $(0.0613)$ & $(0.0610)$ \\
\hline \multirow[t]{2}{*}{$\begin{array}{l}\text { Secondary } \\
\text { completed }\end{array}$} & - & - & - & -0.00369 & 0.0289 & 0.0279 \\
\hline & & & & $(0.0678)$ & $(0.0668)$ & $(0.0667)$ \\
\hline \multirow[t]{2}{*}{$\begin{array}{l}\text { Post- } \\
\text { secondary }\end{array}$} & - & - & - & $0.274^{*}$ & $0.311^{* \star *}$ & $0.291^{*}$ \\
\hline & & & & $(0.147)$ & $(0.147)$ & $(0.154)$ \\
\hline \multicolumn{7}{|l|}{$\begin{array}{l}\text { Age } \\
\text { Categories: } \\
15-18 \\
\text { (Omitted) in } \\
\text { wave 1 }\end{array}$} \\
\hline \multirow[t]{2}{*}{ 19-23 } & - & - & - & $0.0925^{*}$ & 0.0878 & 0.0891 \\
\hline & & & & $(0.0560)$ & $(0.0551)$ & $(0.0553)$ \\
\hline \multirow[t]{2}{*}{$24-28$} & - & - & - & $0.140^{*}$ & $0.141^{* *}$ & $0.138^{*}$ \\
\hline & & & & $(0.0742)$ & $(0.0710)$ & $(0.0713)$ \\
\hline \multirow[t]{2}{*}{ 29-35 } & - & - & - & $0.192^{* \star *}$ & $0.191^{* * *}$ & $0.190^{* * *}$ \\
\hline & & & & $(0.0684)$ & $(0.0667)$ & $(0.0670)$ \\
\hline \multirow[t]{2}{*}{$35-44$} & - & - & - & $0.172^{\star * \star}$ & $0.163^{* * \star}$ & $0.163^{* \star *}$ \\
\hline & & & & $(0.0633)$ & $(0.0588)$ & $(0.0587)$ \\
\hline \multirow[t]{2}{*}{$45-59$} & - & - & - & 0.102 & 0.104 & 0.107 \\
\hline & & & & $(0.0678)$ & $(0.0668)$ & $(0.0664)$ \\
\hline Observations & 2,084 & 2,084 & 2,084 & 2,082 & 2,076 & 2,076 \\
\hline
\end{tabular}

Note: Own estimates using working-age sample of NIDS (SALDRU, 2013a; 2013b; 2013c). Observations weighted using calibrated panel weights Standard errors reported in parentheses. ${ }^{* * *} p<0.01,{ }^{* *} p<0.05$, ${ }^{*} p<0.1$

Individuals residing in households in receipt of social grant income have a lower probability of being employed in wave 3 . This may suggest that grant receiving households provide support while individuals are unemployed but this support may not be sufficient to enable to them to find work. This also supports the idea discussed 
earlier that the unemployed live in households that provide support but that these households are often located in rural areas.

While some unemployed are located in households that receive labour market income through an employed household member or remittances, household wage income has no effect on gaining employment. In both columns 2 and 3, moving has a significant positive effect on finding employment in wave 3 .

In column 4, we include both the household and individual characteristics. Age, as expected, is a significant determinant of employment, individuals between 19 and 44 years old are more likely to gain employment than those in the 15-18 category. Primary and secondary education has a negative impact on gaining employment if unemployed in wave 1 . Those having more than high school education are more likely to gain employment.

It also appears that unemployed women are less likely to gain employment than unemployed men. One possible reason for this may be that it is easier for men to find a job but, at the same time, it may also suggest that men and women move for different reasons. Below in Table 8 separate regressions are shown for men and women. It is clear from Table 7 and 8 that men who move are more likely to be employed when compared to women who move. We see that location is significant for women but not for men. Age is a significant determinant of employment for women but only significant for men between 29 and 35 years.

As expected, being unemployed in an urban area has a positive impact on gaining employment in wave 3. Urban areas in South Africa have lower unemployment rates than rural areas, as we described earlier in Table 1. In Table 8, we show separate regressions for the unemployed who are located in urban and rural areas in wave 1.

Even after accounting for household and individual demographics, the coefficient of moving remains positive and significant. The effect is only slightly diminished.

In column 5, we remove the remittance and the grant income variable. We include the log per capita household income variable instead. The effect of moving remains positive and significant but the impact of the household real log per capita income at baseline is insignificant. As a final check, we control for a movement in wave 2 that might affect employment in wave 3 . The results are reported in column 6 . While moving in wave 3 is only slightly diminished by adding the wave 2 mover dummy variable, the coefficient on wave 2 mover is not significant and thus has no impact on finding employment in wave $3 .{ }^{1}$ 
Table 8: Effect of moving on employment status for the wave 1-unemployed

\begin{tabular}{|c|c|c|c|c|}
\hline & Female & Male & Urban W1 & Rural W1 \\
\hline \multirow[t]{2}{*}{ All movers } & $0.0998^{* *}$ & $0.219^{* \star *}$ & $0.141^{* * *}$ & $0.140^{* * *}$ \\
\hline & $(0.0469)$ & $(0.0737)$ & $(0.0449)$ & $(0.0410)$ \\
\hline \multirow[t]{2}{*}{ Log per capita household income } & -0.0335 & 0.0162 & -0.0111 & -0.0287 \\
\hline & $(0.0242)$ & $(0.0276)$ & $(0.0250)$ & $(0.0321)$ \\
\hline Female (=1) & - & - & $-0.123^{* * *}$ & $-0.176^{* * *}$ \\
\hline Male (omitted) & & & $(0.0442)$ & $(0.0344)$ \\
\hline Urban $(=1)$ & $0.121^{* \star \star}$ & 0.0387 & - & - \\
\hline Rural (omitted) & $(0.0392)$ & $(0.0407)$ & & \\
\hline \multicolumn{5}{|l|}{ Education: No schooling (Omitted) } \\
\hline \multirow[t]{2}{*}{ Primary school } & -0.0155 & $-0.265^{\star \star}$ & $-0.220^{*}$ & -0.0778 \\
\hline & $(0.0822)$ & $(0.114)$ & $(0.117)$ & $(0.0811)$ \\
\hline \multirow[t]{2}{*}{ Some secondary school } & -0.0110 & -0.149 & -0.173 & -0.0320 \\
\hline & $(0.0775)$ & $(0.0967)$ & $(0.111)$ & $(0.0688)$ \\
\hline \multirow[t]{2}{*}{ Secondary completed } & $0.161^{*}$ & -0.133 & -0.0203 & 0.0315 \\
\hline & $(0.0838)$ & $(0.102)$ & $(0.107)$ & $(0.0859)$ \\
\hline \multirow[t]{2}{*}{ Post-secondary } & $0.391^{* *}$ & 0 & 0 & 0.160 \\
\hline & $(0.174)$ & (0) & (0) & $(0.228)$ \\
\hline \multicolumn{5}{|l|}{ Age Categories: 15-18 (Omitted) } \\
\hline \multirow[t]{2}{*}{$19-23$} & $0.140^{* *}$ & 0.0579 & $0.180^{* *}$ & -0.0853 \\
\hline & $(0.0646)$ & $(0.0826)$ & $(0.0771)$ & $(0.0954)$ \\
\hline \multirow[t]{2}{*}{$24-28$} & $0.218^{* * *}$ & 0.0426 & $0.286^{* * *}$ & -0.104 \\
\hline & $(0.0620)$ & $(0.0888)$ & $(0.0727)$ & $(0.112)$ \\
\hline \multirow[t]{2}{*}{$29-35$} & $0.222^{* \star *}$ & $0.215^{* *}$ & $0.278^{* * *}$ & 0.0172 \\
\hline & $(0.0748)$ & $(0.0961)$ & $(0.0830)$ & $(0.0841)$ \\
\hline \multirow[t]{2}{*}{$35-44$} & $0.220^{* \star *}$ & 0.112 & $0.261^{* * *}$ & -0.0164 \\
\hline & $(0.0715)$ & $(0.0932)$ & $(0.0700)$ & $(0.114)$ \\
\hline \multirow[t]{2}{*}{$45-59$} & $0.225^{\star \star \star}$ & -0.0188 & $0.197^{* * *}$ & -0.0638 \\
\hline & $(0.0803)$ & $(0.105)$ & $(0.0656)$ & $(0.137)$ \\
\hline Observations & 1408 & 666 & 985 & 1,089 \\
\hline
\end{tabular}

Note: Own estimates using working-age sample of NIDS (SALDRU, 2013a; 2013b; 2013c). Observations weighted using calibrated panel weights Standard errors reported in parentheses. ${ }^{* *} p<0.01,{ }^{* *} p<0.05$, ${ }^{*} p<0.1$ 


\section{CONCLUSION}

This paper investigates two main survival strategies of the unemployed: to stay in households that provide them with support, or to move to other households in search of employment and/or support. We show, in Table 3, the dispersion of the unemployed, most of whom have access to financial support through labour income or receipt of a state grant by a household member. However, a large proportion of the households receiving remittances or state support are located in rural areas. This moves the unemployed away from the labour market and will reduce their employment prospects and intensity of job search (Klasen and Woolard 2009).

Between $12 \%$ and $18 \%$ of the unemployed in the balanced panel find themselves in households with no connection to the labour market or access to a state grant. It is these households that are likely to be pulled further into poverty through trying to support the unemployed.

In general, household composition appears to be important to the unemployed as they can seek income support from parents and family through co-residency. Where the international literature uses parental characteristics to examine the strategies of the unemployed, this paper goes beyond this and contextualises the economic support the unemployed seek. Taking account of a broader definition of household support, we confirm that the unemployed have a higher propensity to move in search of support or employment. We also confirm that greater gains are being made by the unemployed movers through examination of the change in real log per capita household income. Through our probit regression analysis, we are able to show that moving plays an important role in enabling the unemployed to find a job when taking into account individual and household demographics.

However, moving and searching for a job comes at a cost that is hard to bear for very poor households. This leaves those who are potentially employable stuck in areas far from labour market opportunities. The benefits of gaining employment outweigh the costs, and we see that, despite these costs, the unemployed are in fact moving out and getting ahead. Individuals who gain employment after moving may have more favourable unobservable characteristics than those who remain unemployed after moving. A positive impact of moving on employment may reflect those who have more favourable unobservable employment characteristics. With the use of panel data and a fixed effect model, our method takes into account any timeinvariant unobservable characteristics and our core results remain.

The research approach does not deal with individuals who moved in wave 2 but return to the original wave 1 location in wave 3 . We think that this does not seriously affect our results -as we argue that the employed have higher privacy costs and are unlikely to move back in.

In South Africa, unemployment persists at high levels in both rural and urban areas and there is little direct support of the unemployed. In this environment, private safety nets provide some support and ensure that the majority of the unemployed 
have some way to survive. However, there are still some unemployed who have no private or public safety net and are more susceptible to severe poverty. Other than showing that such unemployed face constrained options in terms of getting ahead, we have not probed the survival strategies of such unemployed and their households. However, this is certainly an important exercise. Similarly, it would be worthwhile for future research to look more deeply into whether or not moving precedes finding a job and how the distance moved affects employment probabilities.

\section{ACKNOWLEDGMENTS}

Amina Ebrahim acknowledges Master's scholarship funding from an NRF Grand Challenges Grant to SALDRU for work on South Africa's Unfolding Human and Social Dynamics.

Murray Leibbrandt acknowledges the Research Chairs Initiative of the Department of Science and Technology and National Research Foundation for funding his work as the Research Chair in Poverty and Inequality.

The authors are grateful to two referees for comments and suggestions made on an earlier version of this paper.

\section{NOTES}

1. We also check for differences in race but find no evidence that race has an effect on our results.

\section{REFERENCES}

Ardington, C., A. Case, and V. Hosegood. 2009. Labor supply responses to large social transfers: Longitudinal evidence from South Africa. American Economic Journal: Applied Economics 1(1) (January): 22-48.

Budlender, D., and F. Lund. 2011. South Africa: A legacy of family disruption. Development and Change 42(4) (July): 925-946.

Card, D., and T. Lemieux. 1997. Adapting to circumstances: The evolution of work, school and living arrangements among North American Youth. NBER Working Paper No. 6142. http:// www.nber.org/papers/w6142 (accessed August 20, 2013)

Cichello, P., M. Leibbrandt, and I. Woolard. 2012. Labour market: Analysis of the NIDS Wave 1 and 2 datasets. Southern Africa Labour and Development Research Unit Working Paper Series 78. http://hdl.handle.net/11090/171 (accessed September 19, 2013)

De Villiers, L., M. Brown, I. Woolard, R. Daniels, and M. Leibbrandt. eds. 2013. National Income Dynamics Study wave 3 user manual. Cape Town: Southern Africa Labour and Development Research Unit. 
Edmonds, E. V., K. Mammen, and D.L. Miller. 2005. Rearranging the family? Income support and elderly living arrangements in a low-income country. Journal of Human Resources 40(1) (Winter): 186-207.

Ermisch, J., and P. Di Salvo. 1997. The economic determinants of young people's household formation. Economica 64(256) (November): 627-644.

Grieger, L., A. Williamson, M. Leibbrandt, and J. Levinsohn. 2013. Moving out and moving in: Evidence of short-term household change in South Africa from the National Income Dynamics Study. A Southern Africa Labour and Development Research Unit Working Paper Number 106, Cape Town: SALDRU, University of Cape Town

Group Areas Act, No. 41 of 1950. Government Gazette 4468, 29 December. Cape Town: Government Printer.

Keller, S. 2004. Household formation, poverty and unemployment: The case of rural South Africa. South African Journal of Economics 72(3) (September): 437-483.

Klasen, S., and I. Woolard. 2009. Surviving unemployment without state support: Unemployment and household formation in South Africa. Journal of African Economies 18(1) (January): $1-51$.

Leibbrandt, M., I. Woolard, F. Arden, and J. Argent. 2010, Trends in South African income distribution and poverty since the fall of apartheid. OECD Social, Employment and Migration Working Paper No. 101. DOI:10.1787/5kmms0t7p1ms-en

Madhavan, S., E. Schatz, S. Clark, and M. Collinson. 2012. Child mobility, maternal status, and household composition in rural South Africa. Demography 49(2) (May): 699-718.

McElroy, M. 1985. The joint determination of household membership and market work: The case of young men. Journal of Labor Economics 3(3) (July): 293-314.

Møller, V., and A. Sotshongaye. 1996. 'My family eat this money too': Pension sharing and selfrespect among Zulu grandmothers. Southern African Journal of Gerontology 5(2): 9-19.

Neves, D., and A. du Toit. 2008. The dynamics of household formation and composition in the rural Eastern Cape. CSSR Working Paper No. 228. http://www.cssr.uct.ac.za/sites/cssr.uct. ac.za/files/pubs/WP228.pdf (accessed August 30, 2013)

Pekkala, S, and H. Tervo. 2002. Unemployment and migration: Does moving help? Scandinavian Journal of Economics 104(4) (December): 621-639.

Posel, D., J.A. Fairburn, and F. Lund. 2006. Labour migration and households: A reconsideration of the effects of the social pension on labour supply in South Africa. Economic Modelling 23(5) (September): 836-853.

Rosenzweig, M.R., and K.I. Wolpin. 1994. Parental and public transfers to young women and their children. American Economic Review 84(5) (December): 1195-1212.

Sagner, A., and R.Z. Mtati. 1999. Politics of pension sharing in urban South Africa. Ageing and Society 19(4) (July): 393-416.

Southern Africa Labour and Development Research Unit (SALDRU). 2013a. National Income Dynamics Study 2012, Wave 3 [dataset]. Version 1.1. Cape Town: Southern Africa Labour and Development Research Unit [producer]. Cape Town: DataFirst [distributor].

Southern Africa Labour and Development Research Unit (SALDRU). 2013b National Income Dynamics Study 2010-2011, Wave 2 [dataset]. Version 2.1. Cape Town: Southern Africa Labour and Development Research Unit [producer]. Cape Town: DataFirst [distributor]. 
Southern Africa Labour and Development Research Unit (SALDRU). 2013c National Income Dynamics Study 2008, Wave 1 [dataset]. Version 5.1. Cape Town: Southern Africa Labour and Development Research Unit [producer]. Cape Town: DataFirst [distributor].

Statistics South Africa (Stats SA). 2014. Quarterly Labour Force Survey, Pretoria: Stats SA.

Thompson, J. 1990. Ideology and modern culture: Critical social theory in the era of mass communication. Cambridge: Polity Press.

Wiemers, E.E. 2014. The Effect of unemployment on household composition and doubling up. Demography 51(6) (December): 2155-2178.

World Bank. 2014. World Development Indicators 2014. Washington, DC: Green Press Initiative. 